\title{
Interesting new record and further notes on the occurrence of marine fish in Nyamithi Pan, Ndumo Game Reserve, South Africa
}

\section{R. KYLE}

Nyamithi Pan, situated in Ndumo Game Reserve, South Africa, is a floodplain pan near the confluence of the Usuthu and Pongolo rivers. It lies approximately $75 \mathrm{~km}$ from the Indian Ocean. The floodplain and its fish have been extensively surveyed (Coke \& Pott 1970; Kok 1980; Merron et al 1993, 1994, 1994a, 1994b, 1994c, 1994d; Pooley 1975 ) and there are many records of the occurrence of marine fish in this and other pans of the Pongolo and Usuthu rivers. These are, however, usually isolated instances of individual fish being caught and attracting attention.

Many of the records (Table 1) are old and the Pongolo and Usuthu river systems have been markedly modified in the last few decades through the construction of dams, particularly the Pongolopoort dam, agriculture and water abstraction. Fishing, mainly gillnetting, has intensified greatly and several exotic fish, particularly Cyprinus carpio (carp) have become well established in many Pon- golo floodplain pans (pers. obs.) in the last few years.

More recent, although erratic, fish monitoring in Nyamithi Pan by EKZN Wildlife staff has yielded some interesting records (Table 2) confirming the continued immigration of some species into the system and also added a new species record for the pan and river systems. More formal, though intensive, fish sampling (Merron et al. 1993, 1994a, 1994b, 1994c) failed to show the presence of any marine fish in Nyamithi. In 1999, tourists reported a dead shark in Nyamithi Pan and on investigation it was found to be a Carcharhinus leucas of almost two metres. Shark fin sightings had been reported for several months but the reason for its death was not clear. There are often well over one hundred Crocodylus niloticus (Nile crocodile) in the pan but the dead shark was mostly intact and it was reported that an adult hippo appeared to be guarding the car-

Table 1

Historical records of the occurrence of marine fish in the Pongolo and Usuthu river systems

\begin{tabular}{|c|c|c|c|c|}
\hline Species & Name & Place & No. & Reference \\
\hline Pristis microdon & Sawfish & Pongolo River & $1(?)$ & Campbell 1969 \\
\hline Carcharhinus leucas & Zambezi shark & $\begin{array}{l}\text { Confluence of } \\
\text { Pongolo/Usuthu }\end{array}$ & $1(?)$ & Crass 1964 \\
\hline Megalops cyprinoides & $\begin{array}{l}\text { Oxeye tarpon } \\
\text { rivers and pans }\end{array}$ & Pongolo \& Usuthu & Several & $\begin{array}{l}\text { Crass } 1964 \\
\text { Coke \& Pott } 1970 \\
\text { Merron et al. } 1994 \mathrm{a}\end{array}$ \\
\hline Mugil cephalus & Bull mullet & Nyamithi pan & Two & Pooley 1975 \\
\hline Acanthopagrus berda & River bream & Pongolo river and pans & Several & $\begin{array}{l}\text { Pooley } 1975 \\
\text { Bruton \& Cooper } 1980\end{array}$ \\
\hline Microphis fluviatilis & Pipefish & Usuthu river & ? & Merron et al. 1993 \\
\hline
\end{tabular}


Table 2

Recent records of marine fish in Nyamithi pan, Ndumo Game Reserve

\begin{tabular}{llll}
\hline Species & Name & Number & Year \\
\hline Carcharhinus leucas & Zambezi shark & 1 & 1999 \\
Megalops cyprinoides & Oxeye tarpon & 1,9 & 1996,2002 \\
Acanthopagrus berda & River bream & 1,1 & 1998 \& 2000 \\
Elops machnata & Springer & 9 & 2002 \\
\hline
\end{tabular}

cass and was seen to drive away any crocodiles which approached the dead fish.

One Megalops cyprinoides was caught in 1996 while, early in 2002, nine more were caught and many more were seen breaking the surface in the manner typical of the species (Skelton 1993). In 1998, one Acanthopagrus berda, of $420 \mathrm{~mm}$ (fork length), was caught, tagged and released and another, smaller, A. berda was caught in 2000 (Tables $1 \& 2$ ).

In early 2002, a total of nine Elops machna$\mathrm{ta}$, of fork lengths $650-800 \mathrm{~mm}$, were caught and released. Several more were seen and the fish were in good condition. These fish represent the first records of this species in these river systems. This species has often been recorded in estuaries, but a survey of the literature ( Bruton \& Kok 1980; Skelton 1993; van der Elst 1998; Whitfield 1998) yielded no mention of $E$. machnata appreciably upstream of estuaries, despite their ability to survive in fresh water.

All the recent Nyamithi records were made during relatively low water levels, several months after any flooding episodes. It seems likely that the fish enter the pan during high flood levels and then stay there for extended periods. The fish were released alive and so not examined internally for gonad condition.

As the $M$. cyprinoides and E. machnata recorded recently were in good condition and the species were still apparently abundant several months after they had immigrated, it appears that they compete well with the Hydrocynus vittatus (tigerfish) which were abundant in the pan at the time. They also appear to survive well in spite of high densities of large C. niloticus. No C. carpio have yet been recorded in Nyamithi, though they are abundant in Namanini Pan, just outside the reserve. It is possible that they fall easy prey to $C$. niloticus.

The most recent records are the first evidence of large scale sustained immigration of $M$. cyprinoides and E. machnata far up rivers. Using Nyamithi as an indicator of the system's fish species composition, it appears that despite their modifications, the immigration of marine species to the Usuthu and Pongolo river systems has not stopped and may have increased in some instances.

\section{Acknowledgements}

I thank Ezemvelo KwaZulu Natal Wildlife for permission to publish this paper.

\section{References}

BRuton, M.N. \& H.M. KoK. 1980. The freshwater fishes of Maputaland. Pp. 210-244. In: Bruton, M.N. \& K.H. Cooper (eds.). Studies on the ecology of Maputaland. Grahamstown: Rhodes University.

CAmpBell, G.C. 1969. A review of scientific investigations in the Tongaland area of northern Natal. Transactions of the Royal Society of South Africa 38(4): 305-316.

Coke, M.M. \& McC. РотT. 1970. The Pongolo floodplain pans. Pietermaritzburg: Natal Parks Board.

CRASS, R.S. 1964. Freshwater fishes of Natal. Pietermaritzburg: Shuter \& Shooter.

KoK, H.M. 1980. Ecological studies on some important fish species of the Pongolo floodplain, KwaZulu, South Africa. PhD. thesis, University of Natal.

Merron, G.S., S.K. Weldrick \& M.N. Bruton. 1993. A fisheries survey of the Phongolo flood- 
plain, Zululand, South Africa-December 1993. J.L.B. Institute of Ichthyology, Grahamstown. (Investigational report; no 45.)

Merron, G.S., S.K.Weldrick \& H. Kaiser. 1994. The second fisheries survey of the Phongolo floodplain, Zululand, South Africa-February 1994. J.L.B. Institute of Ichthyology, Grahamstown. (Investigational report; no 46.)

Merron, G.S., S.K.Weldrick, H. Kaiser \& M.N. BRUTON. 1994a. The third fisheries survey of the Phongolo floodplain, Zululand, South AfricaApril 1994. Institute of Ichthyology, Grahamstown. (Investigational report; no 47.)

Merron, G.S., S.K.Weldrick, H. Kaiser \& M.N. BRUTON. 1994b. The fourth fisheries survey of the Phongolo floodplain, Zululand, South Africa-June 1994. Institute of Ichthyology, Grahamstown. (Investigational report; no 48.)

Merron, G.S., S.K.Weldrick, H. Kaiser \& M.N. BRUTON. 1994c. The fifth fisheries survey of the Phongolo floodplain, Zululand, South Africa-September 1994. Institute of Ichthyolo- gy, Grahamstown. (Investigational report; no 49.)

Merron, G.S., S.K.Weldrick, H. Kaiser \& M.N. BRUTON. 1994d. The sixth fisheries survey of the Phongolo floodplain, Zululand, South AfricaNovember 1994. Institute of Ichthyology, Grahamstown. (Investigational report; no 50.)

Pooley, A.C. 1975. New fish records for Ndumo Game Reserve. Lammergeyer 22: 50-51.

Skelton, P.H. 1993. A complete guide to the freshwater fishes of southern Africa. Halfway House: Southern Book Publishers.

VAN DER ELST. R.P. 1988. A guide to the common sea fishes of southern Africa. Cape Town: Struik.

Whitfield, A.K. 1998. Biology and Ecology of Fishes in Southern African Estuaries. Ichthyological Monographs of the J.L.B. Smith Institute of Ichthyology 2: 1-223.

\section{R. KYLE,}

P.O. Box 43, KwaNgwanase, 3973, South Africa. (Ezemvelo KwaZulu Natal Wildlife;

rkyle@iafrica.com). 